\title{
Deep Well \#4 Backup Power Systems Project Closeout Report
}

April 2010

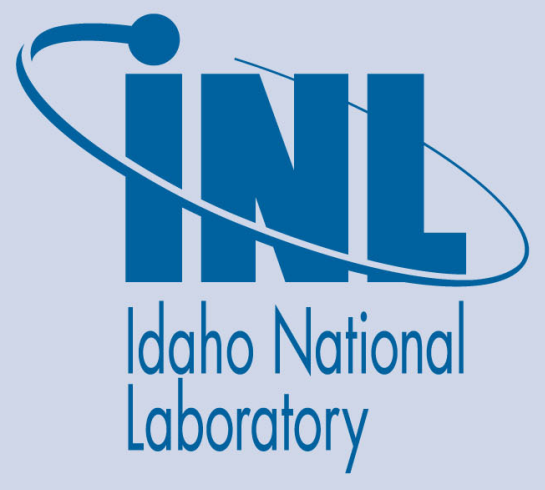

The INL is a U.S. Department of Energy National Laboratory operated by Battelle Energy Alliance 
INL/EXT-10-18385

\title{
Deep Well \#4 Backup Power Systems Project Closeout Report
}

April 2010

\author{
Idaho National Laboratory \\ Idaho Falls, Idaho 83415 \\ Project No. 7A16-A
}

http://www.inl.gov

\author{
Prepared for the \\ U.S. Department of Energy \\ Office of Nuclear Energy \\ Under DOE Idaho Operations Office \\ Contract DE-AC07-05ID14517
}




\section{CONTENTS}

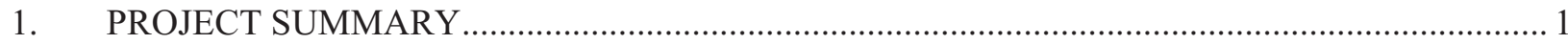

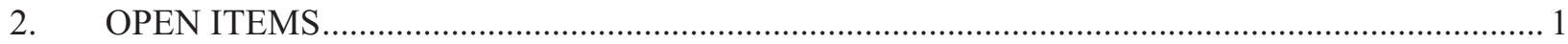

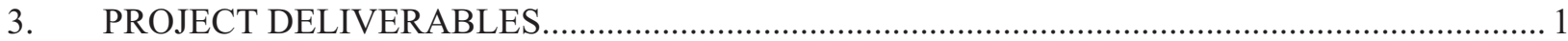

4. PERMITS, LICENSES, ENVIRONMENTAL DOCUMENTATION, WARRANTIES,

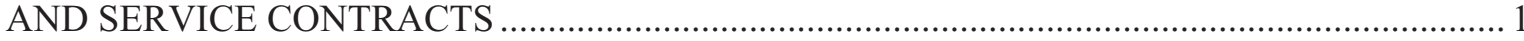

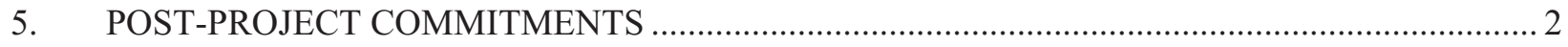

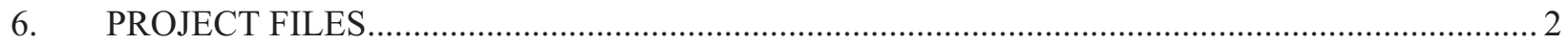

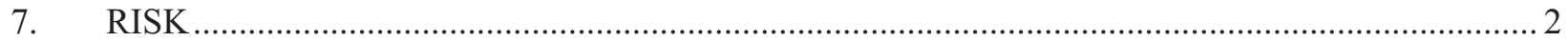

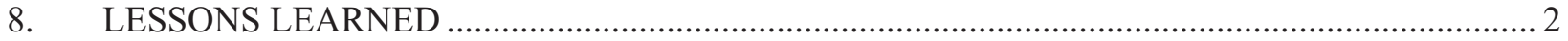




\section{Deep Well \#4 Backup Power Systems Project Closeout Report}

\section{PROJECT SUMMARY}

The project scope was to install a diesel-generated power source to Deep Well \#4 in addition to the existing commercial power source. The diesel power source and its fuel supply system are seismically qualified to withstand a Performance Category 4 seismic event. This diesel power source permits the deep well to operate during a loss of commercial power. System design incorporates the ability to select and transfer power between the new diesel power source and commercial power sources for the the deep well motor and TRA-672 building loads.

The project was initiated as an interim measure in response to recommendations to improve reliability in the mechanical-electrical systems that function to deliver water to storage tanks that supply the Emergency Firewater Injection System for the Advanced Test Reactor (ATR). It should be noted that there is no technical safety requirement for the project other than improved reliability. The interim solution was recommended originally on the basis that a significant amount of time and funding would be required to implement long-term reliability improvements that were being studied as part of work scope of the ATR Life-Extension Program (LEP). The original long-term recommendations and implementation schedule created concern regarding the viability of obtaining a high level of sustained multiyear funding for the Life-Extension Program that is needed to support those recommendations. The Diesel Deep Well \#4 Project was in response to and designed to create some reliability improvement in less than 5 years. However, more recent developments in funding certainty, demonstrated commitment by the Department of Energy to ATR and the Life-Extension Program, and completion of Life-Extension Program reliability and safety improvement objectives would eliminate need for deep well diesels. In summary, the mission need for the project is no longer necessary and it is recommended that $\$ 990,736.85$ of capital recorded on Oracle Project 920097 be written off and the project abandoned.

\section{OPEN ITEMS}

The remaining open item is to complete the abandonment of the project and the write-off of construction-work-in-progress.

\section{PROJECT DELIVERABLES}

The principle project deliverable was a diesel generator, which has been re-stocked by the manufacturer and is no longer INL property. Small items of material that were purchased and delivered for the project and that individually do not require capitalization will be treated as excess property at INL These items include a motor control center, two small transformers, and a pre-engineered metal building. The building will eventually be used as a storage building by the nuclear maintenance organization at the Material and Fuels Complex. The motor control center is in storage at the ATR Complex in anticipation of a future use. The transformers are at Central Facility Area as excess property.

\section{PERMITS, LICENSES, ENVIRONMENTAL DOCUMENTATION, WARRANTIES, AND SERVICE CONTRACTS}

No permits, licenses, environmental documentation, warranties, or service contracts are applicable because the project has been abandoned. All service contracts have been cancelled and no open or outstanding commitments exist. 


\section{POST-PROJECT COMMITMENTS}

No post-project commitments were made or implied.

\section{PROJECT FILES}

Project documentation is located in the Electronic Document Management System.

\section{RISK}

Not applicable (see Section 8).

\section{LESSONS LEARNED}

Two significant circumstances occurred on this project from which lessons can be derived. First, a rigorous trend program was not in place, which would likely have identified the significant scope growth that was occurring from the time of the mission need document and rough-order-of-magnitude estimate to the final scope the project was implementing. This scope growth occurred as engineering systematically solved various problems as design progressed but the associated cost of implementing the design was not being trended. The trend would have identified a cost overrun potential that needed to be addressed by program management to determine whether or not the project was worth pursuing given an accurate estimate at completion. Secondly, accelerating program developments in the Life-Extension Program would, when implemented, satisfy the mission need for a diesel-generator on Deep Well \#4. This gives rise to the need for closer collaboration between projects and programs in order to identify changes that have mutual influence. 